\title{
Report on Four Cases of Chronic Renal Failure Effectively Treated with Astragali Radix
}

\author{
Kazuhiko NAGASAKA Hidehiko FUKUDA Tetsuo WATANABE \\ Yutaka NAGATA \\ Center of Japanese Oriental Medicine, Suwa Central Hospital, 4300 Tamagawa, Chino, Nagano 391-8503, Japan
}

黄耆が奏功した慢性腎不全の 4 症例

長坂 和彦 福田 秀彦 渡辺 哲郎

永田 豊

諏訪中央病院東洋医学センター，長野，广391-8503 茅野市玉川4300番地

\begin{abstract}
Chinese herbal medicine has historically been used for the treatment of renal disease. There are some medicines such as rhubarb and Ompito that delay the need for dialysis. However, they only attenuate the 1/Cr-time slope but cannot reduce the $\mathrm{Cr}$ level. In this study, four chronic renal failure (CRF) patients who had not responded to any Western medicine were treated effectively with Astragali Radix, a traditional herbal medicine. Serum creatinine $(\mathrm{Cr})$ was clearly improved, and necessity for dialysis was delayed. In two patients, $\mathrm{Cr}$ was controlled stably over four years. There were no adverse effects, and no noteworthy changes in the levels of serum phosphorus, potassium and uric acid between before and after treatment were observed. This study suggests that Astragali Radix is a useful agent in the treatment of CRF.

Key words: chronic renal failure, Chinese herbal medicine, Astragali Radix

\section{要旨}

漢方薬はこれまでも腎疾患に応用されてきた。漢方薬の大黄や温脾湯には，透析導入までの期間を延ばす働きが あることが知られている。しかし，その効果は $1 / \mathrm{Cr}$ の傾きを改善するにとどまり， Cr 自体を改善するわけではな い。今回, 西洋薬が無効であった慢性腎不全患者に漢方薬の黄者が奏功した 4 症例を報告する。 4 例とも Cr 值は明 らかに改善し，透析導入までの期間が延長された。このうち2 例は 4 年以上にわたり安定的に推移している。4 例 とも副作用は認めず, また治療前後で血清リン, カリウム, 尿酸值に変化はなかった。黄耆は慢性腎不全の有力な 治療薬となりうる。

キーワード：慢性腎不全, 漢方薬, 黄耆
\end{abstract}

\section{Introduction}

In Asian countries numerous kinds of plants have been used as food, sources for food additives, spices and traditional herbal medicines. Some examples of drugs developed from traditional herbal medicines are ephedrine from Ephedra sinica, morphine from Papaver somniferum, quinine from Cinchona, and cocaine from Erythroxylon coca, among others.

Chinese herbal medicine has been used over the centuries for the treatment of renal disease. However, experimental studies of Kampo medicine for chronic renal failure (CRF) have just started in these past twenty years. Rhubarb and rhubarb containing Ompito (Wen-Pi-Tang in Chinese) can delay the progression of $\mathrm{CRF}^{122}$, but can not reduce the level of Cr. Western medicines such as carbon absorbant
$(\mathrm{AST}-120)^{3)}$ or angiotensin-converting enzyme inhibitors (ACEIs) ${ }^{4}$ improve the $1 / \mathrm{Cr}$-time slope, but they also can not decrease the $\mathrm{Cr}$ level. In the present circumstances, there is still no complete cure for CRF.

In this study Astragali Radix was shown to improve the serum $\mathrm{Cr}$ level without any major side effects. There is very possibility that Chinese medicine can become the treatment of choice for CRF.

\section{Decoction of Astragali Radix}

Fifteen grams of dried Astragali Radix was mixed in $600 \mathrm{ml}$ of water and boiled down to $300 \mathrm{ml}$. The aqueous extract was filtered with a sieve and the resulting decoction was administered 3 times a day before meals. 

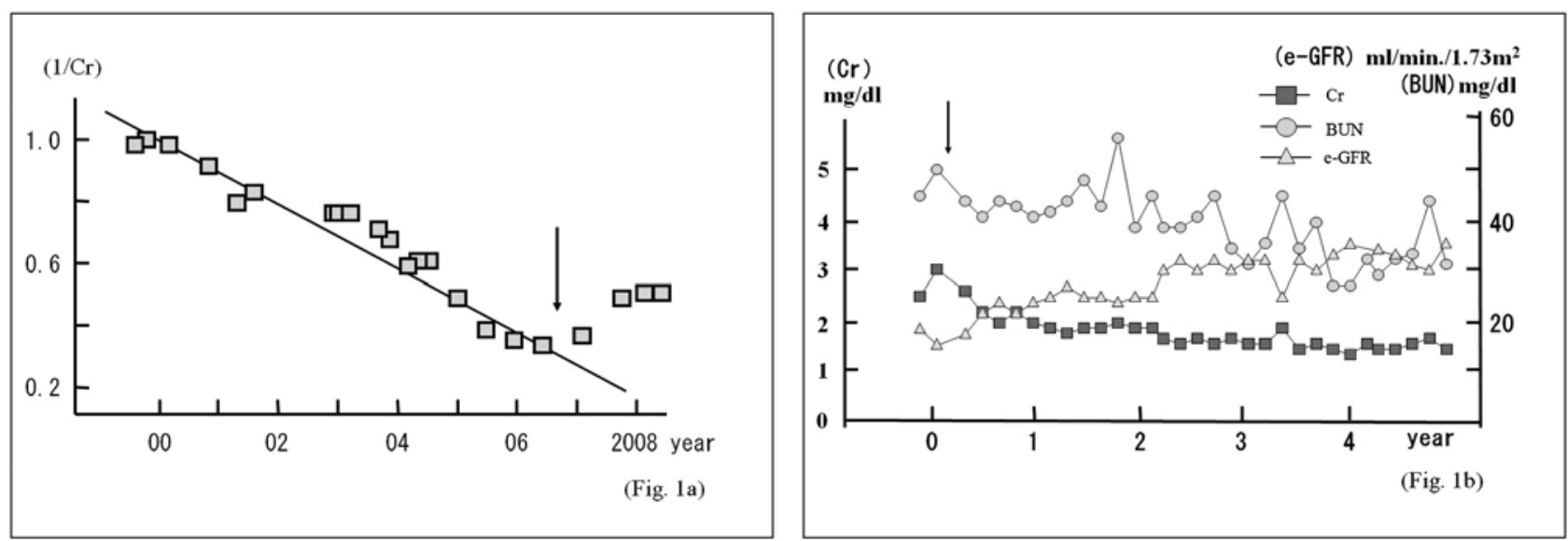

Figure. 1 Clinical course of case 1

(a)1/Cr-time slope up to before and after Kampo treatment is shown. Arrow indicates the start of Kampo treatment. After Kampo treatment 1/Cr-time slope was improved.

(b) Changes of serum Cr, e-GFR and BUN are shown as squares, triangles and circles, respectively. Arrow indicates the start of Kampo treatment. Serum Cr and BUN were improved with Astragali Radix.

\section{Case reports}

We report four CRF patients treated for at least one year with Astragali Radix.

Case 1 was a 15-year-old female with focal glomerulonephritis. At the age of 10, she was diagnosed with albuminuria in a school medical examination. Because of being mentally challenged, with epilepsy and renal insufficiency, she had been hospitalized since fifth grade and treated with enalapril maleate, allopurinol, benzbromarone, sodium bicarbonate, carbamazepine and alfacalcidol. Despite treatment, her $\mathrm{Cr}$ was deteriorating and she was sentenced from attending physician with Fig.1 a that it is necessary for dialysis within a few years. When she visited our hospital her weight was $44 \mathrm{~kg}$ and height was $148 \mathrm{~cm}$. Her heart rate was 62 beats per min and her blood pressure was $98 / 62 \mathrm{mmHg}$. There were no abnormalities in her physical examination except for facial edema. $\mathrm{Cr}$, blood urea nitrogen $(\mathrm{BUN})$ and 24-hour creatinine clearance $(\mathrm{Ccr})$ were $3.0 \mathrm{mg} / \mathrm{dl}, 51 \mathrm{mg} / \mathrm{dl}$ and $22.4 \mathrm{l} / \mathrm{day}$, respectively. Urinalysis showed \pm for protein and none for blood on dipstick examination. After administration of Astragali Radix, her $\mathrm{Cr}$ level improved from 3.0 to $1.49 \mathrm{mg} / \mathrm{dl}$ (Fig.1 b) and Ccr simultaneously showed an increase from 22.4 to $47.1 \mathrm{l} /$ day. Presently, $\mathrm{Cr}$ is controlled in a range of 1.49 to $1.60 \mathrm{mg} /$ dl.

Case 2 was a 59-year-old male. At the age of 41, he could not get insurance because of albuminuria and at the age of 51 he was diagnosed with diabetes. When he visited our hospital his weight was $110 \mathrm{~kg}$ and height was $181 \mathrm{~cm}$. His heart rate was 94 beats per min and his blood pressure was $129 / 79 \mathrm{mmHg}$. Laboratory studies demonstrated normal complete blood count (CBC) and normal serum electrolytes except for potassium $(\mathrm{K})$; $(\mathrm{K}, 5.3 \mathrm{mEq} / \mathrm{l}$; $\mathrm{Cr}, 2.36$ $\mathrm{mg} / \mathrm{dl}$; BUN, $34 \mathrm{mg} / \mathrm{dl}$; glucose, $150 \mathrm{mg} / \mathrm{dl}$; Hba $1 \mathrm{c}, 6.9 \%)$. Urinalysis showed $40-896 \mathrm{mg} / \mathrm{dl}$ of protein. Urinary glucose was not detected. Microscopic evaluation demonstrated 1-4red blood cells per highpower field (HPF) and hyaline casts, granulated casts and waxy casts were seen. It was thought that the renal insufficiency depended on glomerulonephritis rather than on the diabetes, as his control of the diabetes was comparatively good and albuminuria was detected before his diabetes diagnosis. He had B hepatitis and underwent cholecystostomy at 35 years old and 42 years old, respectively. $\mathrm{He}$ had been treated with candesartan cilexetil, amlodipine besilate, glimepiride, pioglitazone hydrochloride, atorvastatin calcium hydrate, allopurinol, aspirin and furosemide but neither renal function (Fig. 2 a) nor urinary protein improved. His $\mathrm{Cr}$ level has ameliorated from 2.36 to $1.55 \mathrm{mg} / \mathrm{dl}$ with Astragali Radix (Fig. 2 b). This past one year, his $\mathrm{Cr}$ has been controlled in a range of 1.55 to $1.82 \mathrm{mg} / \mathrm{dl}$.

Case 3 was a 31-year-old male who, at the age of 13 , presented with proteinuria at a school medical check-up. Renal function gradually worsened from 3-4 years ago in spite of treatment with candesartan cilexetil, amlodipine besilate, atenolol, pravastatin sodium, dipyridamole, allopurinol, imidapril hydrochloride, omeprazole, and carbon absorbent (Fig. 3 a). Fourty-five gram of low protein diet a day has been practied for three years. Physical examination 

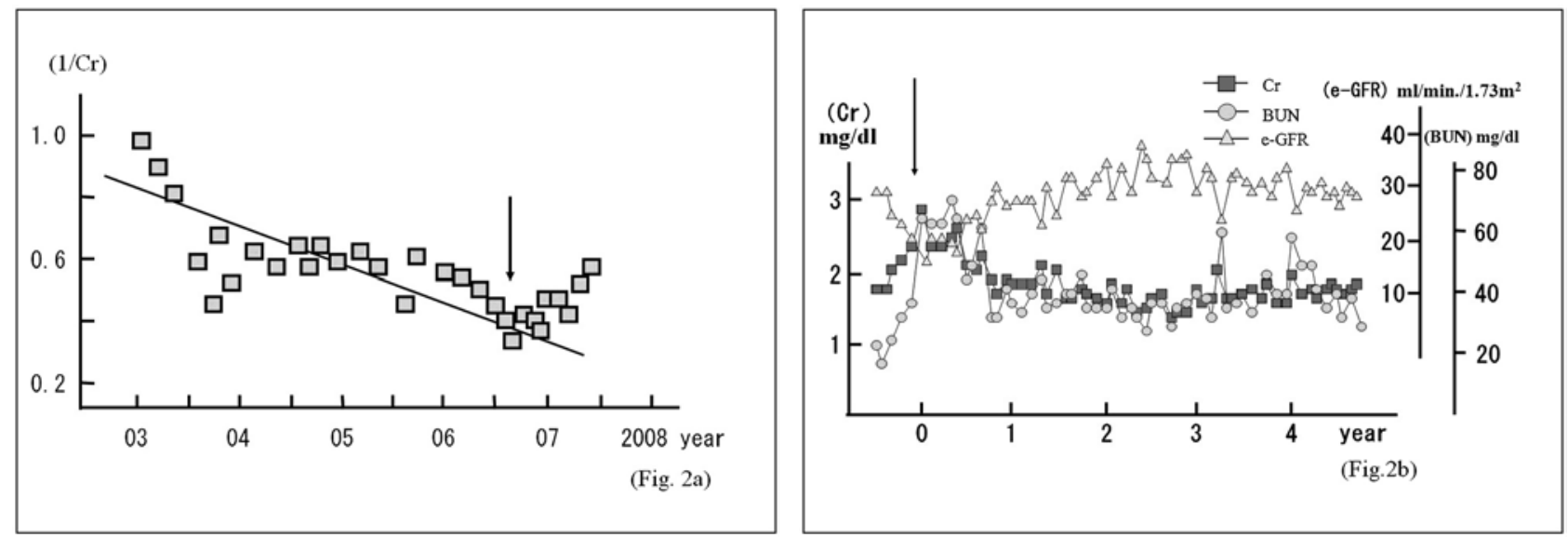

Figure. 2 Clinical course of case 2

(a) $1 / \mathrm{Cr}$-time slope up to before and after Kampo treatment is shown. Arrow indicates the start of Kampo treatment. After Kampo treatment $1 / \mathrm{Cr}$-time slope was improved.

(b) Changes of serum Cr, e-GFR and BUN are shown as squares, triangles and circles, respectively. Arrow indicates the start of Kampo treatment. Serum Cr and BUN were improved with Astragali Radix.
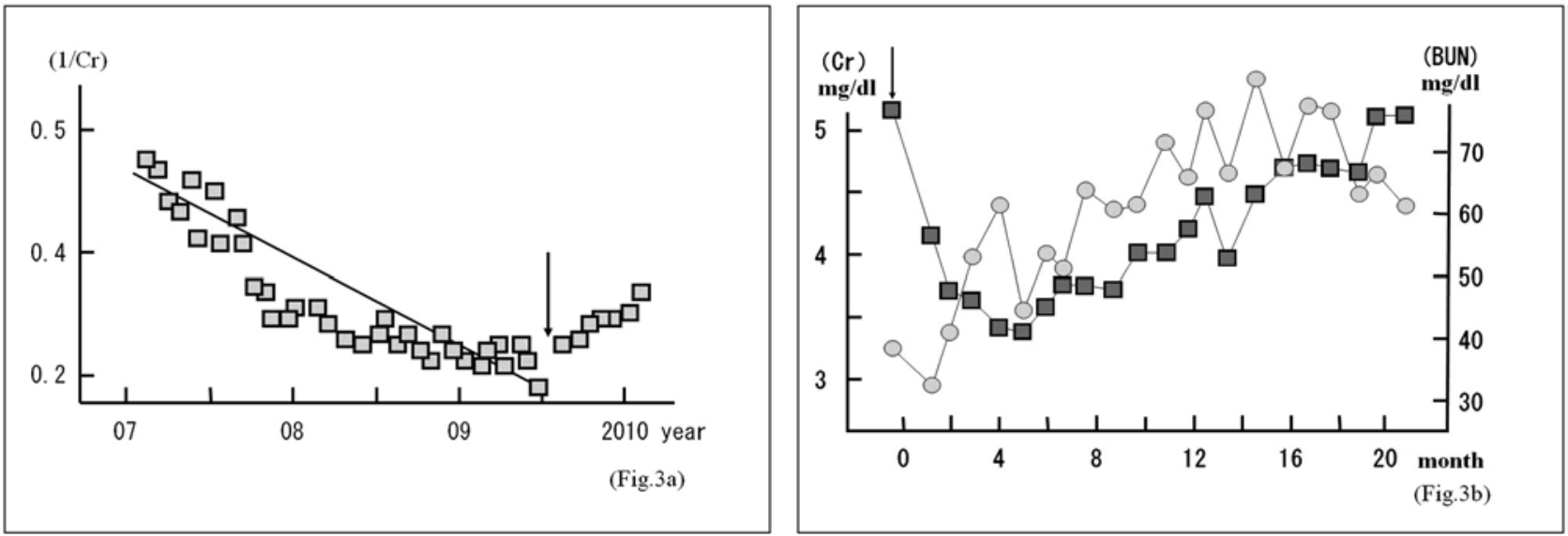

Figure. 3 Clinical course of case 3

(a) 1/Cr-time slope up to before and after Kampo treatment is shown. Arrow indicates the start of Kampo treatment. After Kampo treatment 1/Cr-time slope was improved.

(b) Changes of serum $\mathrm{Cr}$ and BUN are shown as squares and circles, respectively. Arrow indicates the start of Kampo treatment. Serum Cr and BUN were improved with Astragali Radix for first 4 months, but then slowly turned worse. BUN was not improved consistently.

of the patient was unremarkable. When he visited our hospital his weight was $67 \mathrm{~kg}$ and height was $170 \mathrm{~cm}$. His heart rate was 60 beats per min and his blood pressure was $139 / 89 \mathrm{mmHg}$. His father had type 2 diabetes. At 4 months of treatment with Astragali Radix, serum $\mathrm{Cr}$ concentration had improved from 5.32 to $3.34 \mathrm{mg} / \mathrm{dl}$, but it then turned worse slowly again (Fig. 3 b). BUN worsened approximately throughout and $\mathrm{Hb}$ was not improved in spite of using of epoetin alfa.

Case 4 was a 68-year-old male who suffered from acute glomerulonephritis 35 years ago, with persis- tent occult urinary blood and albuminuria thereafter. Since his diagnosis, he underwent annual medical examinations, and his serum $\mathrm{Cr}$ remained below 1.0 $\mathrm{mg} / \mathrm{dl}$ for about 30 years. Because of deterioration of $\mathrm{Cr}$ and BUN, treatment with amlodipine besilate, olmesartan medoxomil, and allopurinol was started 4 years ago, but his $\mathrm{Cr}$ and BUN continued to worsen (Fig. 4 a). At his first visit to our hospital, his weight was $74.7 \mathrm{~kg}$ and height was $165.8 \mathrm{~cm}$. His heart rate was 82 beats per min and his blood pressure was $115 / 72 \mathrm{mmHg}$. Urinalysis showed albuminuria and hematuria with the urinary sediment 

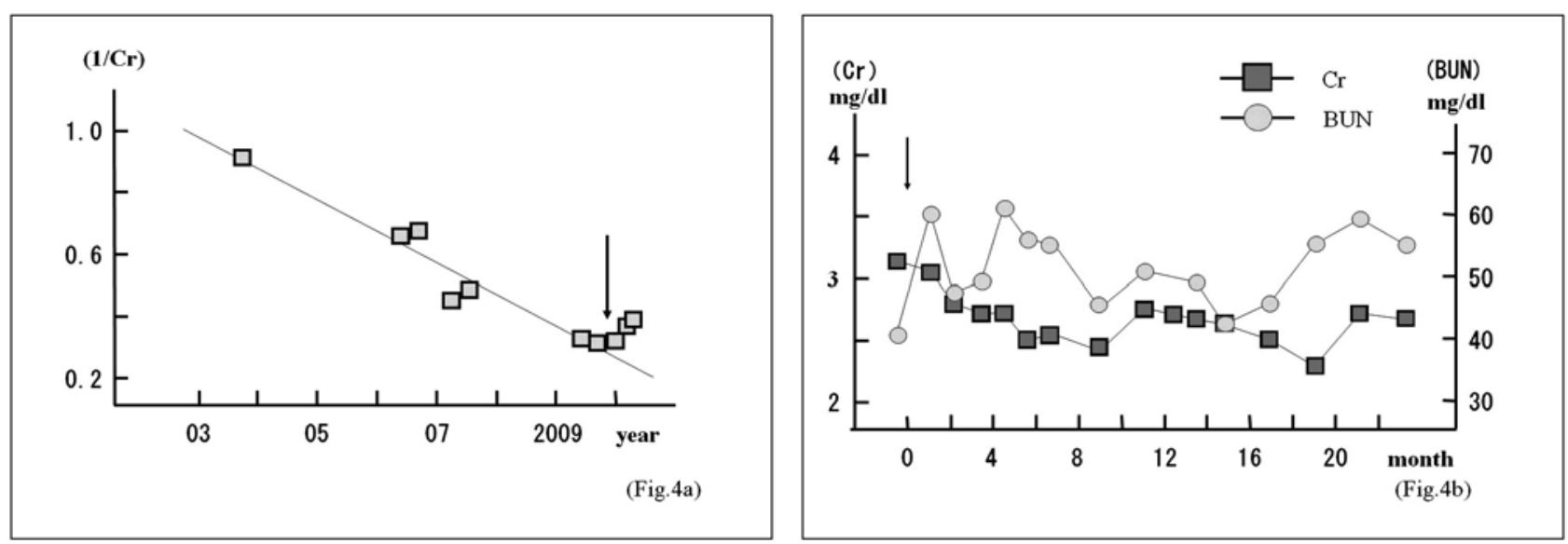

Figure. 4 Clinical course of case 4

(a) 1/Cr-time slope up to before and after Kampo treatment is shown. Arrow indicates the start of Kampo treatment. After Kampo treatment 1/Cr-time slope was improved.

(b) Changes of serum $\mathrm{Cr}$ and BUN are shown as squares and circles, respectively. Arrow indicates the start of Kampo treatment. Serum Cr was improved with Astragali Radix. At the 10 months, the patient participated in a festival on a hot day, and his $\mathrm{Cr}$ worsened from dehydration. BUN was not improved.

containing erythrocytes, hyaline casts, epithelial casts and waxy casts. Physical examination was unremarkable. The patient's social and family histories were unremarkable. His serum $\mathrm{Cr}$ concentrations was improved with Astragali Radix from 3.13 to $2.36 \mathrm{mg} / \mathrm{dl}$ at twenty-month treatment (Fig. 4 b).

All cases of serum $\mathrm{Cr}$ were obviously improved with one year of treatment with Astragali Radix. However, Astragali Radix did not reduce either BUN or the amount of urinary protein. We can not conclude that Astragali Radix improves renal function because Ccr of cases 2, 3 and 4 were not measured, but it is a fact that Astragali Radix delays the necessity for dialysis in patients with CRF. There were no remarkable changes in the levels of serum potassium, phosphorus, and uric acid between before and after treatment.

\section{Discussion}

In recent years, growing numbers of patients have progressed to end-stage renal disease and the medical costs of dialysis have been increasing. Preventing the aggravation of CRF has become a most important problem for nephrologists. There are some medicines such as rhubarb, Ompito and AST-120 that delay the need for dialysis. ACEIs and angiotensin receptor antagonist have been reported to retard progression in patients with early $\mathrm{CRF}$ and albuminuria. However, they only attenuate the $1 / \mathrm{Cr}$ time slope but can not reduce the $\mathrm{Cr}$ level.

Kampo formulae have been used for medical purposes for centuries. Its prescription is not a single, but a mixture of several herbs. Haimoto $\mathrm{H}^{5}$., Ebe $\mathrm{Y}^{6}{ }^{6)}$ and $\mathrm{we}^{7)}$ have reported that Kampo prescriptions that include Astragali Radix significantly improved the serum $\mathrm{Cr}$ level regardless of the underlying disease at any time from the early stage of renal insufficiency to end-stage renal failure. Even if the patients are undergoing dialysis, their $\mathrm{Cr}$ levels will decrease $^{6)}$. This study was designed to estimate the efficacy of Astragali Radix alone.

In Japan, documentations of the pharmacological effects of herbs started in the third decade of the 19 th century. Astragali Radix is one of the representative traditional herbal medicines and has been used historically for the treatment of edema, hypertension, night sweating, viral infection, skin wounds, inflammatory diseases and proteinuria in China and Ja$\operatorname{pan}^{8-11)}$. In recent years, although investigations of herbs have begun to flourish, they are still insufficient.

The quantity of Astragali Radix we used was equivalent to 3-5 times the usual dosage in Japan, but it is the usual dosage in China. As a result of deteriorating renal function, we administered the larger quantity comparable to the dosage used in China. In our previous study, three out of 28 patients who took $30 \mathrm{~g}$ of Astragali Radix a day with other traditional herbs interrupted treatment because of itching ${ }^{7)}$. While they were taking Kampo formulae, serum $\mathrm{Cr}$ was improved successfully. But after interruption of treatment, one case needed dialysis and the other two showed worsening $\mathrm{Cr}$ levels. Then, we set Astragali Radix at $15 \mathrm{~g}$ per day. Adverse ef- 
fects were not observed and there were no remarkable changes in the levels of serum phosphorus, potassium and uric acid between before and after treatment.

In this study, we actually treated five CRF cases. Although cases 2-5 did not undergo renal biopsy, all were thought to have glomerulonephritis, based on their histories of the present illness and laboratory data. Treatment with Astragali Radix alone resulted in a Cr-lowering effect in all cases. One of the five cases stopped taking Astragali Radix for a while because of aortocoronary bypass surgery (case 5), and was excluded. But while being treated with Astragali Radix, his Cr level improved from 1.97 to 1.67.

Astragali Radix had a useful effect on the Cr level, but it could not change BUN. The diuretic action of Astragali Radix might be one of the reasons for this, but it can not explain all of it. The fact that serum $\mathrm{Cr}$ and $\mathrm{Ccr}$ were improved simultaneously in case 1 suggests that Astragali Radix probably acts directly on glomerular function. In any case, Astragali Radix avoid or at least delays the necessity for dialysis in patients with CRF, and those who interrupted Astragali Radix-containing Kampo treatment had rapid deterioration of renal function in a previous study. This strongly suggests that this Chinese medicine may become a first-choice therapeutic option for CRF.

\section{Conclusion}

Astragali Radix reduced the serum $\mathrm{Cr}$ level without any major side effects. But Astragali Radix did not improve BUN, proteinuria and anemia. Astragali Radix avoid or at least delays the necessity for dialysis in patients with CRF. This study suggests that Astragali Radix is a useful agent in the treatment of CRF.

\section{References}

1) Yokozawa T, Suzuki N, Zheng D P, Oura H, Nishioka I. : Effect of orally administered Rhubarb extract in rats with chronic renal failure. Chem Pharm Bulletin. 32, 45064513, 1984

2 ) Mitsuma T, Yokozawa T, Oura H, Terasawa K, Narita M. : Clinical evaluation of Kampo medication, mainly with Wen-Pi-Tang, on the progression of chronic renal failure. Jap J Nephrology ( in Japanese ). 4, 769-777, 1999

3 ) Sanada T, Akizawa T, Koide K, Koshikawa S. : Protective effect of an oral adsorbent on renal function in chronic renal failure : Determinants of its efficacy in diabetic nephropathy. Therapeutic Apheresis and Dialysis. 8, 232-240, 2004

4 ) Domenico R, Robert M, Antonio P, Raffaela E, Giuseppe S, Michele A, et al. : Coadministration of Losartan and Enalaperil additive antiproteinuric effect in IgA nephropathy. Am. J Kidney Disease. 38, 18-25, 2001

5 ) Haimoto H. : Astragali Radix has a powerfull effect on a decline of serum creatinine in patients with chronic renal failure. J. phytotherapy ( in Japanese ). 7, 4-9,. 2005

6 ) Ebe Y.: Effective treatment of gouty nephropathy induced chronic renal failure with the "nourishing the kidney and depressant turbid dampness decoction”. J Kampo, Acupuncture and Integrative Med.1, 21-22, 2006

7 ) Nagasaka K, Fukuda H, Hashimoto M, Ebe K, Ebe Y. : Yozinkodakuto, a traditional Chinese (Japanese Kampo) medicine, improves the creatinine level in chronic renal failure. Trad Med.24, 87-89, 2007

8 ) Kobe Chuigaku Kenkyukai: Kanyaku no rinsyo. Ishiyaku Publishers ( in Japanese ), Inc. Tokyo, 1986

9 ) Nagasaka K, Tosa H, Tatsumi T, Shimada Y, Itou T.: Four cases report of intractable pressure ulcers effectively treated with Kigi-kenchu-to-ka-bushi. Kampo Med (in Japanese). 49, 273-80, 1998

10) Nagasaka K, Hikiami H, Tatsumi T, Tosa H. : The influence of Kampo medicine on the disease activity in fiftyfour patients with rheumatoid arthritis (in Japanese). Rheumatology. 27, 481-487, 2002

11) Shimotani T.: A case of nephritic syndrome that responded well to the administration of high dose of Ogi. Eastern Med ( in Japanese). 17, 61-67, 2001 